Beata Kunat

Uniwersytet w Białymstoku

\title{
Potrzeby i oczekiwania nauczycieli plastyki w zakresie wspierania ich rozwoju zawodowego - komunikat z badań
}

\section{Wprowadzenie}

We właściwie realizowanej szkolnej edukacji plastycznej najważniejszą rolę odgrywa dobrze przygotowany nauczyciel plastyki - profesjonalista odznaczający się wysoką motywacją oraz w pełni świadomy jej celów ${ }^{1}$. Nauczyciel plastyki, ze względu na charakter i specyfikę edukacji artystycznej, realizuje szczególnie złożone zadania i funkcje. Jego ważna rola polega na stymulowaniu twórczej postawy uczniów wobec świata oraz przygotowaniu ich do jego indywidualnego postrzegania, odczuwania i interpretowania ${ }^{2}$. Kompetentny nauczyciel plastyki kształtuje otwartą postawę uczniów wobec szeroko rozumianej kultury, przyczynia się do rozbudzenia ich wrażliwości wobec drugiego człowieka ${ }^{3}$. W obliczu złożoności zadań edukacji plastycznej, wynikających z przemian społeczno-kulturalnych, zmian zachodzących w sztuce, w postawach twórczych i odbiorczych ${ }^{4}$, nauczyciel plastyki stoi przed koniecznością nieustannego rozwoju własnej osobowości, podnoszenia własnej kultury ogólnej i pedagogicznej $j^{5}$, a w konsekwencji ciągłego rozwoju zawodowego. W raporcie Impact of Culture on Creativity podkreślono, że kształcenie i rozwój zawodowy nauczycieli jest jednym z obszarów, który wymaga poprawy, ponieważ to oni wistotny sposób

\footnotetext{
${ }^{1}$ Por.: S. Popek, W poszukiwaniu wyznaczników modelu nauczyciela plastyki, [w:] K. Olbrycht (red.), Kształcenie pedagogów realizujących wychowanie plastyczne - w'świetle aktualnych potrzeb edukacyjnych i uwarunkowań społeczno-kulturowych, Cieszyn 1998, s. 41.

${ }^{2}$ Por.: D. Łada, Sztuka celem i środkiem wychowania, [w:] L. Kataryńczuk-Mania, J. Karcz (red.), Edukacja artystyczna wobec przemian społeczno-oświatowych, Zielona Góra 2002, s. 47.

${ }^{3}$ Por.: M. Szymańska, Status nauczyciela plastyki w systemie kształcenia estetycznego (na podstawie badań przeprowadzonych w szkołach płockich), [w:] J. Piekarski, L. Tomaszewska, M. Szymańska (red.), Kształcenie pedagogów - strategie, koncepcje, „Zeszyty Naukowe. Pedagogika” 2007, t. VI, s. 339 .

${ }^{4}$ Por.: A. Pola, Miejsce plastyki w edukacji permanentnej, „Plastyka w Szkole” 1990, nr 5, s. 213.

${ }^{5}$ Por.: A. Pikała, Dokształcanie, doskonalenie zawodowe nauczycieli powszechnego wychowania estetycznego w kontekście potrzeb i uwarunkowań społeczno-kulturalnych, Łódź 2008, s. 51.
} 
wpływają na generowanie kreatywnego środowiska dydaktycznego w szkołach $^{6}$. Z raportu Arts and Cultural Education at School in Europe wynika zaś, że do procesu rozwoju zawodowego nauczycieli przedmiotów artystycznych, w tym nauczycieli plastyki, nie przywiązuje się specjalnej wagi ${ }^{7}$. Badania Anne Bamford dowodzą, że w podnoszeniu rangi i jakości edukacji artystycznej największe znaczenie ma wspieranie nauczycieli przedmiotów artystycznych w procesie ich ustawicznego rozwoju zawodowego ${ }^{8}$. Wsparcie rozwoju zawodowego nauczycieli powinno polegać na tworzeniu optymalnych warunków tego procesu oraz rozpoznaniu i zaspokajaniu potrzeb nauczycieli w tym zakresie ${ }^{9}$. Podstawowy warunek rozwoju zawodowego nauczycieli to zaspokajanie ich psychospołecznych potrzeb, wynikających z istoty pracy pedagogicznej. Muszą być one zaspokajane w sposób ciągły i pewny, dlatego gwarancją intensyfikacji rozwoju zawodowego nauczycieli jest ich regularne ocenianie ${ }^{10}$. Badania dowodzą, że nauczyciele plastyki nie są wspierani w procesie rozwoju zawodowego przez nadzór pedagogiczny i doradztwo metodyczne ${ }^{11}$.

Wychodząc z powyższych założeń, uznałam, że istnieje konieczność szerszego zdiagnozowania tego problemu. Przede wszystkim - rozpoznania potrzeb i oczekiwań nauczycieli plastyki w zakresie wspierania ich rozwoju zawodowego, a w konsekwencji - opracowania projektu działań ukierunkowanych na wspieranie tego procesu.

\footnotetext{
${ }^{6}$ Zob.: Impact of Culture on Creativity, KEA European Affairs 2009.

${ }^{7}$ Badania komparatystyczne nad szkolną edukacją artystyczną i kulturalną w 30 krajach odnoszące się do roku szkolnego 2007-2008. Zob.: Arts and Cultural Education at School in Europe, Brussels 2009, s. 76-77.

${ }^{8}$ Zob.: A. Bamford, The Wow Factor: Global Research Compendium on the Impact of the Arts in Education, New York 2009.

${ }^{9}$ Teza ta wynika z badań i publikacji dotyczących wsparcia rozwoju zawodowego nauczycieli. Zob.: B. Murawska, E. Putkiewicz, R. Dolata, Wsparcie rozwoju zawodowego a potrzeby nauczycieli w tym zakresie, Warszawa 2005; także: A. Szczęsna, Wsparcie społeczne w rozwoju zawodowym nauczycieli, Zielona Góra 2010; J. Jones, M. Jenkin, S. Lord, Jak wspierać rozwój zawodowy nauczycieli, tłum. K. Sip, Warszawa 2008.

${ }^{10}$ D. Hargreaves, [za:] Ch. Day, Rozwój zawodowy nauczyciela. Uczenie się przez całe życie, tłum. J. Michalak, Gdańsk 2004, s. 27.

${ }^{11}$ Badania dotyczące rozwoju zawodowego nauczycieli plastyki publicznych szkół podstawowych i gimnazjalnych miasta Białystok prowadzone w 2005 r. Zob.: B. Kunat, Trudny zawód nauczycieli plastyki, „Edukacja i Dialog” 2007, nr 1, s. 50-54.
} 


\section{Metodologiczne podstawy badań własnych}

Przedmiotem badan ${ }^{12}$ uczyniłam potrzeby i oczekiwania nauczycieli plastyki w zakresie wspierania ich rozwoju zawodowego, który zgodnie z przyjętymi przeze mnie koncepcjami Ralpha Fesslera ${ }^{13}$ i Michaela Hubermana ${ }^{14}$, traktuję całościowo jako dynamiczny i wieloetapowy proces, stanowiący transformację doświadczeń nauczycieli związanych z ich całożyciowym uczeniem się i „stawaniem się”.

W swoim projekcie wyłoniłam następujące problemy badawcze: Jakie są potrzeby nauczycieli plastyki w zakresie tworzenia optymalnych warunków ich rozwoju zawodowego? Jakie są oczekiwania nauczycieli plastyki wobec różnych podmiotów w kwestii wspierania ich rozwoju zawodowego?

Zastosowałam metodę sondażu diagnostycznego ${ }^{15}$, a w jej ramach dwie techniki badawcze: ankietę i wywiad. Narzędziami badawczymi były autorskie kwestionariusze ankiety i wywiadu. Próbę badawczą stanowiła populacja 87 nauczycieli plastyki ${ }^{16}$. Badanych dobrałam w sposób celowy ${ }^{17}$. Badania właściwe prowadziłam osobiście od października 2009 do kwietnia 2011 roku na terenie 115 szkół publicznych podstawowych i gimnazjalnych usytuowanych w Białymstoku (57 szkół) oraz na terenie powiatu białostockiego - 58 szkół mieszczących się w obrębie 15 gmin.

\footnotetext{
${ }^{12}$ Fragment badań prowadzonych w ramach rozprawy doktorskiej nt. Rozwój zawodowy nauczycieli plastyki (stan, specyfika, uwarunkowania) napisanej pod kierunkiem naukowym dr. hab. Włodzimierza Prokopiuka, prof. Uniwersytetu w Białymstoku.

${ }^{13}$ Zob.: R. Fessler, Dynamic of teacher career stages, [w:] T. R. Guskey, M. Huberman (eds.), Professional Development in Education: New Paradigms and Practices, New York 1995, s. 171-192.

${ }^{14}$ Zob.: M. Huberman, Professional careers and professional development: Some intersections, [w:] T. R. Guskey, M. Huberman (eds.), Professional Development in Education..., s. 193-224.

${ }^{15}$ Zob.: T. Pilch, T. Bauman, Zasady badań pedagogicznych. Strategie ilościowe i jakościowe, Warszawa 2001, s. 79-82.

${ }^{16}$ Zbadałam wszystkich czynnych zawodowo nauczycieli plastyki publicznych szkół podstawowych i gimnazjów miasta Białystok i powiatu białostockiego.

${ }^{17}$ Kryteria doboru: formalny poziom wykształcenia, stopień awansu zawodowego nauczycieli, usytuowanie środowiskowe szkół - miejsca pracy. Charakterystyka badanej zbiorowości nauczycieli plastyki: formalny rodzaj wykształcenia (kwalifikacje do nauczania plastyki): 43,7\% nauczycieli plastyki ukończyło kierunek edukacja plastyczna, 42,5\% - kierunek inny niż edukacja plastyczna + studia sztuka; 13,8\% badanych ukończyło kierunek inny niż edukacja plastyczna + kurs kwalifikacyjny sztuka; stopień awansu zawodowego: 16,1\% - nauczyciele kontraktowi, 25,3\% - nauczyciele mianowani, 58,6\% - nauczyciele dyplomowani; usytuowanie środowiskowe szkół - miejsca pracy: $52,1 \%$ - nauczyciele szkół miasta Białystok, 22,4\% - nauczyciele szkół miasta powiatu białostockiego, 25,5\% nauczyciele wiejskich szkół powiatu białostockiego.
} 


\section{Analiza wyników badań własnych}

Ze zgromadzonego przeze mnie materiału empirycznego wynika, że nauczyciele plastyki mają różne potrzeby w zakresie kształtowania optymalnych warunków ich rozwoju zawodowego. Podstawową potrzebą 87,2\% nauczycieli plastyki, sprzyjająca ich rozwojowi zawodowemu, jest zapewnienie im realizacji etatu w jednej placówce, co byłoby gwarantem stabilizacji zawodowej. To mogłoby zostać rozwiązane poprzez zwiększenie liczby godzin plastyki. Ważna potrzeba $77,9 \%$ badanych polega na stworzeniu dobrych warunków materialno-organizacyjnych w szkole. W tym zakresie nauczyciele oczekują urządzenia pracowni plastycznych i wyposażenia ich w materiały, narzędzia, pomoce dydaktyczne, sprzęt audiowizualny. W zakresie warunków organizacyjnych szkoły oczekują: zmniejszenia liczby uczniów w klasie oraz możliwości prowadzenia zajęć plastycznych w systemie blokowym. Ustaliłam, że 62,1\% nauczycieli plastyki potrzebuje wsparcia finansowego, np. zwrotu kosztów poniesionych na doskonalenie zawodowe oraz zakup materiałów plastycznych. Niezbędnym oczekiwanym warunkiem wsparcia procesu rozwoju zawodowego wyrażanym przez $62,7 \%$ badanych okazało się ustanowienie etatu doradcy metodycznego nauczycieli plastyki o wykształceniu pedagogiczno-plastycznym, posiadającego duże doświadczenie w zakresie edukacji artystycznej. 61,6\% badanych potrzebuje zwiększenia oferty doskonalenia zawodowego. Istotną potrzebą 60,4\% respondentów jest docenianie ich pracy przez terenowy nadzór pedagogiczny, profesjonalną grupę odniesienia, dyrekcję oraz rodziców. $58,1 \%$ badanych oczekuje traktowania równorzędnego $\mathrm{z}$ nauczycielami innych przedmiotów, a przez to podniesienia rangi nauczycieli plastyki i przedmiotu plastyka w szkole. Odnotowałam też potrzebę poważnej części badanych $(72,0 \%)$ zwiększenia świadomości społecznej w kwestii roli edukacji plastycznej w rozwoju osobowości człowieka. Kolejna grupa potrzeb formułowanych przez nauczycieli dotyczy współpracy szkoły ze środowiskiem społecznym. 51,1\% badanych oczekuje współpracy z artystami, animatorami kultury oraz pracownikami muzeów, galerii sztuki, ośrodków kultury, 23,2\% nauczycieli potrzebuje współpracy z rodzicami swoich uczniów, a także samorządem lokalnym (19,77\%). Ważny nurt potrzeb nauczycieli plastyki w zakresie tworzenia optymalnych warunków ich rozwoju zawodowego dotyczy wsparcia tego procesu. $38,3 \%$ badanych potrzebuje wsparcia ze strony szkolnego nadzoru pedagogicznego, 29,0\% responden- 
tów - ze strony innych nauczycieli. Oczekiwanym przez 19,7\% nauczycieli plastyki źródłem wsparcia ich rozwoju zawodowego jest samorząd lokalny.

Analiza wyników badań wskazuje na to, że potrzeby nauczycieli plastyki w zakresie tworzenia optymalnych warunków ich rozwoju są zróżnicowane ze względu na rodzaj ich wykształcenia, stopień awansu zawodowego oraz usytuowanie ich miejsca pracy. Potrzeby 94,5\% absolwentów kierunków pedagogiczno-plastycznych dotyczą zwiększenia świadomości społecznej w zakresie edukacji plastycznej. 89,4\% nauczycieli-specjalistów oczekuje stworzenia dobrych warunków organizacyjno-materialnych szkoły. 86,8\% $\mathrm{z}$ nich formułuje potrzebę równorzędnego traktowania $\mathrm{z}$ nauczycielami innych przedmiotów. Zwiększenie prestiżu przedmiotu plastyka jest ważne dla 55,2\% tych nauczycieli. 91,8\% nauczycieli innych przedmiotów, którzy ukończyli dodatkowo studia podyplomowe o kierunku: sztuka, potrzebuje stabilizacji zawodowej dzięki możliwości realizacji etatu w jednej placówce edukacyjnej oraz zwiększenia liczby godzin plastyki. W tej grupie $83,7 \%$ nauczycieli za ważny warunek wspierania ich rozwoju zawodowego uznaje stworzenie etatu doradcy metodycznego. W przypadku 27,0\% badanych wsparcie ze strony samorządu terytorialnego stanowi istotną potrzebę optymalizacji ich rozwoju zawodowego. Konkretnego wsparcia i pomocy w rozwoju zawodowym oczekują nauczyciele, którzy ukończyli inny kierunek niż edukacja plastyczna oraz kurs kwalifikacyjny „sztuka”. 91,6\% z nich wyraża potrzebę zwiększenia oferty doskonalenia zawodowego. 83,3\% nauczycieli oczekuje wsparcia finansowego. Ta grupa kieruje swoje oczekiwania w zakresie wspierania rozwoju zawodowego do doradztwa metodycznego (83,3\% nauczycieli), dyrekcji szkoły (58,3\%) oraz innych nauczycieli (50,0\%). Najwięcej potrzeb w zakresie tworzenia optymalnych warunków rozwoju zawodowego wyrażają nauczyciele kontraktowi. 100,0\% z nich wyraża świadomość braku własnej stabilizacji zawodowej i za niezwykle ważne uznaje umożliwienie im realizacji etatu w jednej placówce. Wsparcia ze strony dyrekcji oczekuje 92,8\% nauczycieli kontraktowych, 85,7\% z nich w realizacji własnego rozwoju zawodowego potrzebuje pomocy finansowej i stworzenia etatu doradcy metodycznego. Towarzysząca nauczycielom kontraktowym świadomość niepewności na rynku pracy oraz niski prestiż przedmiotu plastyka sprawiają, że 78,5\% respondentów oczekuje szczególnego wsparcia ze strony doradztwa metodycznego. $64,2 \%$ badanych potrzebuje pomocy w tym zakresie ze strony innych nauczycieli. Oczekiwania wobec samorządu terytorialnego wyraża 35,75\% nauczycieli kontraktowych. 
Wraz ze zwiększającymi się: świadomością zawodową oraz poczuciem stabilizacji nauczycieli mianowanych inaczej kształtują się też potrzeby w zakresie tworzenia optymalnych warunków do realizowania własnego rozwoju zawodowego. Wszyscy nauczyciele mianowani podkreślają konieczność traktowania ich równorzędnie z nauczycielami innych przedmiotów. 86,3\% respondentów ma na uwadze potrzebę zwiększania świadomości społecznej w zakresie edukacji plastycznej. Dobre warunki organizacyjno-materialne szkoły stanowią czynniki wspierania rozwoju zawodowego dla 81,8\% nauczycieli mianowanych. Docenianie pracy nauczyciela plastyki za ważne uznaje 72,7\% z nich. Za istotne w tworzeniu optymalnych warunków sprzyjających procesowi rozwoju zawodowego 68,1\% badanych uważa zwiększenie oferty doskonalenia zawodowego. Najmniej oczekiwań w zakresie tworzenia warunków wspierających rozwój zawodowy formułują nauczyciele dyplomowani. Nie potrzebują oni konkretnej pomocy, lecz wsparcia procesu własnego rozwoju zawodowego upatrują w kontekście współpracy z różnymi podmiotami, a zwłaszcza ze środowiskiem artystycznym. Usytuowanie szkoły, w której pracują badani nauczyciele, także różnicuje potrzeby w aspekcie tworzenia optymalnych warunków ich rozwoju zawodowego. $85,7 \%$ nauczycieli zatrudnionych w Białymstoku sygnalizuje potrzebę tworzenia lepszych warunków organizacyjnych szkoły. Taka sytuacja jest związana m.in. z dużą liczebnością klas, brakiem podziału na grupy, niedostatecznym zapleczem materialnym szkoły. Największe oczekiwania mają nauczyciele plastyki szkół miast i wsi powiatu białostockiego. Wyraźnie zaznaczają się potrzeby: stabilizacji zawodowej, stworzenia etatu doradcy metodycznego oraz zwiększenia oferty doskonalenia zawodowego.

Badani nauczyciele plastyki oczekują wsparcia rozwoju zawodowego od wielu podmiotów: dyrekcji szkoły, innych nauczycieli, rodziców uczniów, doradztwa metodycznego, środowiska artystycznego (instytucji kultury) oraz samorządu terytorialnego.

Najwięcej oczekiwań badani kierują wobec dyrektora szkoły jako źródła wsparcia ich rozwoju zawodowego na różnych płaszczyznach. 98,8\% badanych zwraca uwagę na konieczność tworzenia przez dyrektorów dobrej bazy materialnej szkoły. Wsparcia finansowego ze strony dyrekcji oczekuje $94,2 \%$ nauczycieli plastyki. Motywowania do własnego rozwoju zawodowego pragnie $88,5 \%$ badanych. Na docenianie pracy, zrozumienie i akceptację przez szkolny nadzór pedagogiczny liczy $71,2 \%$ z nich. Potrzebę umożliwiania udziału w doskonaleniu zawodowym sygnalizuje 70,1\% nauczycieli. 
Za niezwykle istotne uznaje 63,2\% respondentów kreowanie przez dyrekcję podmiotowych relacji interpersonalnych w szkole. 55,1\% badanych zwraca uwagę na konieczność zatrudniania na stanowisku nauczycieli plastyki specjalistów. Niewiele powyżej 40\% nauczycieli oczekuje od dyrektorów szkół: pomocy w udostępnianiu najnowszej literatury fachowej; prezentowania ciekawych innowacji i projektów; przekazywania rzetelnej informacji. 39,0\% badanych pragnie gratyfikacji za dodatkową pracę, a wsparcia i pomocy w rozwiązywaniu problemów oczekuje 31,0\% nauczycieli plastyki. Nauczyciele plastyki zwracają uwagę na to, że indywidualne cechy osobowościowe dyrektorów: ich życzliwość, uczciwość, fachowość, poszanowanie innych w istotnym stopniu wpływają na jakość rozwoju zawodowego nauczycieli. Oczekiwania badanych wobec dyrekcji w zakresie wsparcia ich rozwoju zawodowego odnoszą się również do stylu zarządzania szkołą, zwłaszcza do umiejętności kształtowania partnerskich relacji interpersonalnych w szkole, sprawności organizacyjnych związanych ze sprawiedliwym podziałem zadań i odciążania nauczycieli od nadmiernych obowiązków związanych z dekoracjami, organizacją imprez szkolnych i dyżurami. Badani oczekują postawy dyrektora, określanej przez J. Jonesa, M. Jenkin, S. Lord jako „promująca rozwój zawodowy nauczyciela” poprzez tworzenie przyjaznego klimatu umożliwiającego ciągły rozwój oraz udoskonalanie umiejętności ${ }^{18}$. Działania dyrektorów wzmacniające rozwój zawodowy, których potrzebują badani, wpisują się w rodzaj przywództwa wspierającego ${ }^{19}$, gdyż oczekują oni od przełożonego okazywania im zaufania, zachęcania do innowacji, nagradzania oraz wsparcia poprzez zwiększanie szans na rozwój zawodowy. Badania Anny Szczęsnej dotyczące wsparcia społecznego nauczycieli w rozwoju zawodowym także wskazują na to, że oczekują oni od dyrektora przywództwa wpierającego. Pośród pożądanych działań autorka wymieniła: nagradzanie, docenianie, dbanie o dobrą atmosferę, wspieranie w doskonaleniu i pomoc w rozwiązywaniu problemów ${ }^{20}$.

Dane empiryczne świadczą, iż ważną grupę wsparcia nauczycieli plastyki w procesie rozwoju zawodowego stanowi profesjonalna grupa odniesienia (inni nauczyciele). Oczekiwania nauczycieli plastyki wobec innych nauczycieli głównie dotyczą „wymiany doświadczeń” poprzez wsparcie, rozmowę, konsultację i poradę (87,3\%). 79,3\% nauczycieli deklaruje chęć

\footnotetext{
${ }^{18}$ Por.: J. Jones, M. Jenkin, S. Lord, Jak wspierać rozwój zawodowy nauczycieli..., s. 121-122.

${ }^{19}$ J. Blase i G. Anderson, [za:] Ch. Day, Od teorii do praktyki. Rozwój zawodowy nauczycieli, tłum. J. Michalak, Gdańsk 2008, s. 133-134.

${ }^{20}$ Zob.: A. Szczęsna, Wsparcie społeczne w rozwoju zawodowym nauczycieli..., s. 151-154.
} 
współpracy i współdziałania z profesjonalną grupą odniesienia. Nauczyciele plastyki od grona pedagogicznego potrzebują „kultury współpracy” opartej na spontanicznych, dobrowolnych relacjach, która jest podstawowym czynnikiem wpływającym na ich rozwój zawodowy ${ }^{21}$. 66,6\% nauczycieli oczekuje ze strony profesjonalnej grupy odniesienia: doceniania, zrozumienia, aprobaty, pochwały. Respondenci oczekują, by inni członkowie grona pedagogicznego rozumieli istotę i rolę edukacji artystycznej. Ponad $60 \%$ respondentów oczekuje pomocy i wzajemnego wspierania się, szczególne w realizacji imprez szkolnych oraz w przygotowywaniu dekoracji. Istotnym obszarem oczekiwań 39,0\% badanych wobec innych nauczycieli jest sprawiedliwy przydział dodatkowych obowiązków i zadań. 24,1\% badanych oczekuje od innych nauczycieli, aby mieli oni szacunek do zawodu nauczyciela plastyki, traktując go na równi z innymi.

Nauczyciele plastyki formułują także oczekiwania wobec rodziców uczniów jako źródła wsparcia ich rozwoju zawodowego. Materiał badawczy wskazuje, iż ponad połowa badanych $(54,8 \%)$ oczekuje ze strony tych podmiotów zmiany świadomości w zakresie edukacji plastycznej. 35,4\% respondentów pragnie, by rodzice zrozumieli, jak ważną rolę odgrywa plastyka w rozwoju człowieka, a w konsekwencji, by byli bardziej zainteresowani i zaangażowani w działalność plastyczną swoich dzieci. 27,4\% nauczycieli potrzebuje docenienia ich pracy przez rodziców oraz traktowania plastyki na równi z innymi przedmiotami. Znaczna część badanych potrzebuje wsparcia praktycznego i materialnego ze strony rodziców uczniów. 29,0\% respondentów oczekuje współpracy i pomocy w realizacji przedsięwzięć szkolnych oraz w wyposażeniu dzieci w materiały plastyczne.

Do środowiska profesjonalnego nauczycieli, które może stanowić źródło wsparcia jego rozwoju zawodowego, należą instytucje współpracujące ze szkołą, zwłaszcza ośrodki doradztwa zawodowego. Istnieje kilka nurtów oczekiwań nauczycieli plastyki wobec doradztwa metodycznego. Dotyczą one form i dziedzin doskonalenia zawodowego, a także źródeł dostarczania informacji na jego temat. Badani nauczyciele plastyki głównie oczekują od doradztwa metodycznego organizacji spotkań umożliwiających wymianę doświadczeń z innymi nauczycielami plastyki. Do form wsparcia nauczycieli plastyki w rozwoju zawodowym przez doradców metodycznych, oczekiwanych przez 66,6\% badanych, należy organizowanie staży krajowych i zagranicznych. Pomocy w udostępnieniu najnowszej literatury oczekuje

\footnotetext{
${ }^{21}$ Zob.: Ch. Day, Od teorii do praktyki..., s. 126.
} 
54,0\% badanych. Konieczność organizowania konferencji, odczytów, seminariów przedmiotowo-metodycznych, warsztatów, szkoleń i kursów z zakresu edukacji plastycznej oraz zajęć otwartych zgłasza 48,2\% respondentów. Indywidualnych konsultacji z doradcą metodycznym potrzebuje 37,9\% nauczycieli. Na potrzebę dyżurów doradcy metodycznego w szkołach wskazuje $27,5 \%$ badanych. 11,4\% nauczycieli plastyki za ważne uznaje promowanie twórczości plastycznej poprzez organizację w ośrodkach metodycznych wystaw i warsztatów tematycznych we współpracy ze środowiskiem artystycznym. Oczekiwania nauczycieli plastyki wobec doradztwa metodycznego w zakresie wsparcia ich rozwoju zawodowego skoncentrowane są wokół kilku nurtów problemowych: promowania twórczości plastycznej, dydaktyki, pedagogiki, psychologii, a także sfery organizacyjnej procesu dydaktyczno-wychowawczego. Największa grupa nauczycieli $(71,2 \%)$ oczekuje od doradztwa wsparcia na płaszczyźnie promowania twórczości plastycznej, głównie poprzez prezentowanie ciekawych innowacji, programów i projektów z zakresu sztuki. Oczekiwania 64,3\% badanych dotyczą wsparcia w dziedzinie dydaktyki i doskonalenia warsztatu pracy. $62,2 \%$ respondentów oczekuje promowania i upowszechniania nowych metod, technik pracy. Ważnym oczekiwaniem $40,2 \%$ badanych jest potrzeba rozbudowania systemu wsparcia w zakresie trudnych problemów wychowawczych. 17,2\% nauczycieli plastyki oczekuje od doradztwa metodycznego wspierania ich $\mathrm{w}$ negocjacjach $\mathrm{z}$ rodzicami i innymi reprezentantami środowiska edukacyjnego. 20,6\% nauczycieli potrzebuje pomocy w prowadzeniu dokumentacji szkoły, np. przy wyborze podręczników, programów nauczania. 13,7\% badanych oczekuje zwiększenia przepływu informacji na temat oferty doskonalenia zawodowego organizowanej przez doradztwo metodyczne. Nauczyciele plastyki domagają się, by do szkół przesyłano oferty doskonalenia zawodowego skierowane do tej grupy zawodowej. $\mathrm{Z}$ mojego materiału empirycznego wynika, że obecny wkład doradców w rozwój zawodowy nauczycieli plastyki jest niewielki. Tezę o niedostatecznym wsparciu nauczycieli przez doradztwo zawodowe potwierdzają także analizy empiryczne H. Dybek ${ }^{22}$ oraz badania prowadzone w Pracowni Badań Społecznych w Sopocie ${ }^{23}$.

Ważne źródło wsparcia nauczycieli plastyki w realizacji ich zadań zawodowych stanowi działalność instytucji kultury. Z badań wynika, że funk-

\footnotetext{
${ }^{22}$ Zob.: H. Dybek, Doradztwo metodyczne i doskonalenie zawodowe nauczycieli, Kraków 2000, s. 150 .

${ }^{23}$ Zob.: B. Murawska, E. Putkiewicz, R. Dolata, Wsparcie rozwoju zawodowego..., s. 61-64.
} 
cjonuje szeroka sieć współpracy między białostockimi szkołami a środowiskiem artystycznym. Nauczyciele plastyki do form wsparcia w realizacji swojego rozwoju zawodowego zaliczają ofertę edukacyjną białostockich instytucji kultury. Pozytywne relacje i współpraca ze środowiskiem artystycznym wspierają rozwój zawodowy nauczycieli plastyki. 51,7\% badanych pragnie stworzenia sieci współpracy szkoły i instytucji kultury. Dobrym wsparciem byłyby działania animatorów, artystów-plastyków organizowane na terenie szkoły oraz promowanie twórczości plastycznej uczniów w instytucjach kultury (wystawy ich prac w muzeach, galeriach). 44,8\% nauczycieli potrzebuje oferty edukacyjnej instytucji kultury skierowanej do szkół, a zwłaszcza do ich grupy zawodowej. W celu upowszechniania sztuki nauczyciele oczekują, by artyści-plastycy byli bardziej otwarci na działania szkolne. Chcą, by organizowali oni własne wystawy, warsztaty, spotkania na terenie szkół lub zapraszali uczniów do swoich pracowni plastycznych. 33,3\% nauczycieli plastyki oczekuje stworzenia przez środowisko artystyczne korzystnych warunków finansowych realizacji ich oferty edukacyjnej. Zasadniczą kwestią jest wprowadzenie zniżek lub nieodpłatnego udziału uczniów w działaniach organizowanych przez instytucje kultury (np. w wystawach, warsztatach, wykładach). Kolejny nurt oczekiwań wobec środowiska artystycznego związany jest rozszerzeniem pakietu informacyjnego, np. zaproszeń kierowanych do szkół na wystawy, wernisaże, warsztaty $(24,1 \%)$.

Zobowiązane do działań na rzecz rozwoju zawodowego nauczycieli są jednostki samorządu terytorialnego, które stanowią podmioty powołane do prowadzenia szkół i placówek ${ }^{24}$. Z moich badań wynika, że nauczyciele plastyki oczekują od samorządu lokalnego głównie wsparcia finansowego (71,2\%): w wyposażaniu pracowni w sprzęt multimedialny i materiały plastyczne. Potrzebują oni dotacji na działalność artystyczną i inicjatywy kulturalne na uczestnictwo uczniów w kulturze oraz na dodatkowe zajęcia plastyczne. 58,6\% badanych zwraca uwagę na konieczność zainteresowania ze strony samorządu lokalnego wydarzeniami artystycznymi organizowanymi przez szkoły w celu podniesienia ich prestiżu w środowisku.

\footnotetext{
${ }^{24}$ Ustawa z dnia 7 września 1991 r. o systemie oświaty (Dz.U. z 2004, nr 256, poz. 2572 ze zm.).
} 


\section{Konkluzje wynikające z badań}

Analiza wyników badań, z perspektywy koncepcji wsparcia społecznego Stanisława Kawuli ${ }^{25}$, świadczy o tym, że oczekiwania nauczycieli plastyki wobec różnych podmiotów w zakresie wspierania ich rozwoju zawodowego dotyczą głównie wsparcia instrumentalnego, wartościującego, emocjonalnego i informacyjnego. W kwestii wsparcia instrumentalnego nauczyciele oczekują dostarczenia konkretnej pomocy: przygotowania pracowni plastycznych wyposażonych w materiały, narzędzia, pomoce dydaktyczne oraz sprzęt audiowizualny; zwrotu kosztów doskonalenia zawodowego, zakupu materiałów plastycznych; wynagrodzenia za dodatkową pracę np. za dekoracje i nadgodziny; umożliwienia udziału w dostępnych zewnętrznych formach doskonalenia nauczycieli, np. warsztatach, kursach, konferencjach, sympozjach, seminariach; pomocy w rozwiązywaniu konkretnych problemów, np. w rozumieniu przepisów formalnych („biurokracji”), w zdobywaniu funduszy na materiały plastyczne. Grupa oczekiwań wobec różnych podmiotów o charakterze wsparcia wartościującego dotyczy głównie nagradzania poprzez gratyfikację finansową, wyróżnienia, odznaczenia. Oczekiwane przez nauczycieli plastyki działania wspierające na poziomie emocjonalnym to: docenianie, zrozumienie, akceptacja, a także wyrażanie aprobaty i podziękowań za zrealizowane zadania. Kategorie oczekiwań nauczycieli plastyki kierowanych wobec różnych grup na poziomie wsparcia informacyjnego dotyczą udostępniania szerszej informacji z różnych zakresów doskonalenia zawodowego. Obok wsparcia szkolnej profesjonalnej grupy odniesienia nauczyciele plastyki potrzebują sieci i różnego rodzaju partnerstwa. Nawiązując do teorii cykli uczenia się Michaela Hubermana, można wysnuć wniosek, że są oni nastawieni na „otwarty cykl zbiorowy” swojego rozwoju zawodowego ${ }^{26}$ i oczekują wielkoobszarowej pracy zespołowej.

\footnotetext{
${ }^{25} \mathrm{~W}$ koncepcji S. Kawuli wsparcie jako spirala życzliwości rozpatrywane jest na pięciu poziomach: wsparcia instrumentalnego polegającego na dostarczaniu konkretnej pomocy, świadczenia usług; wsparcia wartościującego, czyli przekazywania komunikatów typu: „jesteś dla nas kimś znaczącym”; wsparcia emocjonalnego związanego z dawaniem komunikatów typu np. „jesteś nasz”, „lubimy cię", „masz mocne cechy charakteru”; wsparcia informacyjnego polegającego na udzielaniu rad, informacji, które mogą pomóc w rozwiązywaniu problemu; wsparcia duchowego (psychiczno-rozwojowego) stosowanego, gdy nie pomagają żadne inne formy pomocy. Zob.: S. Kawula, Spirala życzliwości: od wsparcia do samorozwoju, [w:] E. Kantowicz (red.), Wsparcie społeczne w różnych układach ludzkiego życia, Olsztyn 1997, s. 16.

${ }^{26}$ Zob.: M. Huberman, Networks that alter teaching, „Teachers and Teaching: Theory and Practice" 1995, nr 1, s. 206.
} 


\section{Wnioski dla praktyki pedagogicznej}

Wyniki moich badań świadczą o tym, że potrzebna jest strategia wsparcia rozwoju zawodowego, głównie nauczycieli rozpoczynających pracę. Powinni być oni otoczeni szczególną opieką, gdyż start zawodowy stanowi najważniejszy etap rozwoju zawodowego, który może być źródłem „rozczarowania” (rezygnacji z pracy) lub źródłem „oczarowania” (pierwszych sukcesów, poczucia satysfakcji zawodowej). Z przyjętych przeze mnie w badaniach teorii rozwoju zawodowego nauczyciela M. Hubermana i R. Fesslera wynika, że rozpoczynanie kariery zawodowej/wprowadzenie do zawodu jest związane $\mathrm{z}$ nastawieniem początkującego nauczyciela na przetrwanie bądź odkrywanie i jest to czas wprowadzenia do zawodu nauczyciela Początkowy okres życia uważany jest za krytyczny (rozstrzygający) $\mathrm{w}$ procesie rozwoju zawodowego nauczycieli. Na tym etapie nauczyciele potrzebują akceptacji w środowisku szkolnym, wsparcia ze strony dyrekcji i doświadczonych nauczycieli. Oczekują od tych podmiotów współpracy, a także pomocy w rozwiązywaniu konkretnych problemów. Kolejną grupą, do której powinno być skierowane wsparcie, są nauczyciele innych przedmiotów, którzy zostali uprawnieni do prowadzenia plastyki po ukończeniu kursu kwalifikacyjnego z zakresu „sztuki”. Z badań wynika, że nauczyciele plastyki ze szkół wiejskich i miejskich powiatu białostockiego funkcjonują poza systemem wsparcia ze strony doradztwa metodycznego (brak doradcy metodycznego). Istnieje pilna potrzeba wypełnienia tej luki.

Reasumując, warto jest podjąć celowe działania zmierzające do stworzenia nauczycielom plastyki optymalnych warunków sprzyjających ich rozwojowi zawodowemu, a szczególnie rozbudowywanie sieci wsparcia tego procesu w środowisku. Nauczyciele plastyki, w kontekście wsparcia rozwoju zawodowego, oczekują współpracy i partnerstwa ze strony profesjonalnej grupy odniesienia: rady pedagogicznej, dyrekcji oraz sieci różnego rodzaju wsparcia typu: współpraca z rodzicami uczniów, z doradztwem metodycznym, środowiskiem artystycznym, samorządem lokalnym. Potrzebne jest zatem wieloobszarowe wsparcie rozwoju zawodowego ze strony różnych źródeł osobowych. Istnieje konieczność tworzenia wewnątrzszkolnej i zewnętrznej sieci ich wsparcia oraz promowania „kultury współpracy i partnerstwa" opartej na spontanicznych, dobrowolnych relacjach. Zasadne jest zatem kształtowanie autorskiego dla każdej szkoły stylu instytucji wspólnie 
uczących się podmiotów, budowanie „organizacji uczącej się” ${ }^{27}$. Szkoła jako „organizacja ucząca się" akcentuje takie zjawiska, jak: uczenie się zespołowe oparte na doświadczeniu i autorefleksji; prowadzenie badań samokształceniowych; zaangażowanie; wypracowywanie oryginalnych strategii działania pedagogicznego; partnerstwo; współpraca; otwarta komunikacja; wiązanie rozwoju osobistego nauczycieli z rozwojem szkoły jako organiza$\mathrm{cji}^{28}$. Uczące się organizacje zdolne są do samopoznania, rozumienia swoich problemów i doskonalenia się ${ }^{29}$. Propozycją wspomagania nauczycieli w ich permanentnym „stawaniu się" może być tworzenie w środowisku pracy różnych przestrzeni uczenia się $e^{30}$. Szansą dla nauczyciela jest szkoła postrzegana jako miejsce indywidualnego i zespołowego uczenia się nauczycieli poprzez tworzenie wspólnot praktyków - uczących się społeczności nauczycielskich ${ }^{31}$.

Od nauczycieli plastyki i od tego, jak rozumieją oni potrzebę własnego rozwoju zawodowego, w znacznej mierze zależy edukacja plastyczna i właściwy rozwój osobowy uczniów w tym zakresie, dlatego należy im się szczególna pomoc ze strony różnych grup wsparcia, by nie czuli się „wykorzystywani" i niedoceniani. Konieczne jest wspieranie rozwoju zawodowego nauczycieli plastyki poprzez kształtowanie optymalnych warunków tego procesu, takich jak:

- stabilna polityka oświatowa w zakresie szkolnej edukacji plastycznej (zwiększenie liczby godzin plastyki, podniesienie prestiżu przedmiotu plastyka w szkole),

- zmiana zasad awansu zawodowego (usprawnienie systemu awansu zawodowego, niekoncentrowanie się na czynnościach administracyjnych, ale na doskonaleniu kompetencji zawodowych),

- stabilizacja zawodowa i finansowa nauczycieli plastyki (realizacja etatu w jednej placówce),

- docenianie pracy nauczycieli plastyki przez profesjonalną grupę odniesienia (dyrekcję, nauczycieli, uczniów, rodziców uczniów) oraz terenowy nadzór pedagogiczny,

${ }^{27}$ Zob.: W. Dróżka, Kształcenie i rozwój zawodowy nauczyciela w przestrzeni organizacji uczacej się, „Edukacja” 2004, nr 4, s. 33.

${ }^{28}$ Por.: ibidem, s. 35.

${ }^{29}$ Por.: E. Potulicka, Uczący się nauczyciel, szkoła, społeczeństwo, [w:] T. Bauman (red.), Uczenie się jako przedsięwzięcie na całe życie, Kraków 2005, s. 273.

${ }^{30}$ Zob.: J. M. Michalak, Przestrzenie uczenia się nauczycieli: uczenie się w środowisku pracy, „Edukacja” 2009, nr 4, s. 22-33.

${ }^{31}$ Por.: ibidem, s. 33. 
- dobre warunki materialne szkoły (wystarczająca baza materialna szkoły, pracownie wyposażone w materiały, narzędzia, pomoce dydaktyczne, sprzęt audiowizualny),

- właściwe (sprzyjające) warunki organizacyjne szkoły (zmniejszenie liczby uczniów w klasie, możliwość prowadzenia zajęć plastycznych w systemie blokowym),

- wsparcie finansowe (zwrot kosztów doskonalenia zawodowego, zakup materiałów plastycznych),

- intensyfikacja wsparcia doradczego nauczycieli plastyki (zatrudnianie na stanowisku doradcy metodycznego specjalisty o przygotowaniu z zakresu edukacji plastycznej, zwiększenie oferty doskonalenia zawodowego kierowanej do nauczycieli plastyki),

- zorganizowanie sieci współpracy szkół z lokalnymi instytucjami kultury, fundacjami, stowarzyszeniami, placówkami związanymi z edukacją plastyczną, m.in. z muzeami i galeriami sztuki, ośrodkami kultury, szkołami o profilu artystycznym oraz uczelniami kształcącymi nauczycieli.

\section{Bibliografia}

Arts and Cultural Education at School in Europe, Brussels 2009.

Bamford A., The Wow Factor: Global Research Compendium on the Impact of the Arts in Education, New York 2009.

Day Ch., Od teorii do praktyki. Rozwój zawodowy nauczycieli, tłum. J. Michalak, Gdańsk 2008.

Day Ch., Rozwój zawodowy nauczyciela. Uczenie się przez całe życie, tłum. J. Michalak, Gdańsk 2004.

Dróżka W., Kształcenie i rozwój zawodowy nauczyciela w przestrzeni organizacji uczącej się, „Edukacja” 2004, nr 4.

Dybek H., Doradztwo metodyczne i doskonalenie zawodowe nauczycieli, Kraków 2000.

Fessler R., Dynamic of teacher career stages, [w:] T. R. Guskey, M. Huberman (eds.), Professional Development in Education: New Paradigms and Practices, New York 1995.

Huberman M., Networks that alter teaching, „Teachers and Teaching: Theory and Practice" 1995, No. 1.

Huberman M., Professional careers and professional development: Some intersections, [w:] T. R. Guskey, M. Huberman (eds.), Professional Development in Education: New Paradigms and Practices, New York 1995.

Impact of Culture on Creativity, KEA European Affairs 2009. 
Jones J., Jenkin M., Lord S., Jak wspierać rozwój zawodowy nauczycieli, tłum. K. Sip, Warszawa 2008.

Kawula S., Spirala życzliwości: od wsparcia do samorozwoju, [w:] E. Kantowicz (red.), Wsparcie społeczne w różnych układach ludzkiego życia, Olsztyn 1997.

Kunat B., Trudny zawód nauczycieli plastyki, „Edukacja i Dialog” 2007, nr 1.

Łada D., Sztuka celem i środkiem wychowania, [w:] L. Kataryńczuk-Mania, J. Karcz (red.), Edukacja artystyczna wobec przemian społeczno-oświatowych, Zielona Góra 2002.

Michalak J. M., Przestrzenie uczenia się nauczycieli: uczenie się w środowisku pracy, „Edukacja" 2009, nr 4.

Murawska B., Putkiewicz E., Dolata R., Wsparcie rozwoju zawodowego a potrzeby nauczycieli w tym zakresie, Warszawa 2005.

Pikała A., Dokształcanie, doskonalenie zawodowe nauczycieli powszechnego wychowania estetycznego w kontekście potrzeb i uwarunkowań społeczno-kulturalnych, Łódź 2008.

Pilch T., Bauman T., Zasady badań pedagogicznych. Strategie ilościowe i jakościowe, Warszawa 2001.

Potulicka E., Uczący się nauczyciel, szkoła, społeczeństwo, [w:] T. Bauman (red.), Uczenie się jako przedsięwzięcie na całe życie, Kraków 2005.

Pola A., Miejsce plastyki w edukacji permanentnej, „Plastyka w Szkole” 1990, nr 5.

Popek S., W poszukiwaniu wyznaczników modelu nauczyciela plastyki, [w:] K. Olbrycht (red.) Kształcenie pedagogów realizujących wychowanie plastyczne - w świetle aktualnych potrzeb edukacyjnych i uwarunkowań społeczno-kulturowych, Cieszyn 1998.

Szczęsna A., Wsparcie społeczne w rozwoju zawodowym nauczycieli, Zielona Góra 2010.

Szymańska M., Status nauczyciela plastyki w systemie kształcenia estetycznego (na podstawie badań przeprowadzonych w szkołach płockich), [w:] J. Piekarski, L. Tomaszewska, M. Szymańska (red.), Kształcenie pedagogów - strategie, koncepcje, „Zeszyty Naukowe. Pedagogika" 2007, t. VI, cz. 1. 